УДК: 377.4

Євеліна ЦАРЬОВА, виконувач обов'язків директора Державного навчального закладу "Хмельницький центр професійно-технічної освіти сфери послуг"

\title{
РОЛЬ МАЙСТРА ВИРОБНИЧОГО НАВЧАННЯ У ФОРМУВАННІ ПРОФЕСІЙНОЇ МОБІЛЬНОСТІ МАЙБУТНЬОГО ФАХІВЦЯ
}

\author{
Evelina TSAREVA, Acting Director State Education Establishment \\ Khmelnytskyi vocational training centre services sector
}

\section{THE ROLE MASTER OF MANUFACTURING TRAINING IN FORMING PROFESSIONAL MOBILITY OF THE FUTURE SPECIALIST}

\begin{abstract}
У статті здійснено аналіз різноманітних підходів до визначення сутності понятя "професійна мобільність". Висвітлено роль професійної мобільності у кар'єрному зростанні майбутніх кваліфікованих робітників. Зроблено висновок про те, що провідну роль у формуванні професійної мобільності майбутніх фахівців відіграють майстри виробничого навчання, професійний розвиток яких забезпечує система методичної роботи закладу професійної (професійно-технічної) освіти. Подано основні форми методичної роботи (на прикладі Державного навчального закладу "Хмельницький центр професійно-технічної освіти сфери послуг") щодо професійного розвитку майстрів виробничого навчання з метою забезпечення формування професійної мобільності майбутніх фахівців сфери послуг.

Ключові слова: професійна мобільність, кар'єрне зростання, професійна (професійно-технічна) освіта, майстер виробничого навчання.
\end{abstract}

Summary. The article analyzes various approaches to the definition of the concept of professional mobility. The role of professional mobility in the career growth of future skilled workers is highlighted. It is concluded the masters of production training play a leading role in shaping the professional mobility of future professionals. The system of methodical work of vocational (vocational training) education provides their professional development of future specialists. The main forms of methodological work are

(C) Є. Царьова provided (on the example of Khmelnytskyi State Education Establishment vocational training centre services sector). It is concerning professional development of the masters of production training in order to ensure the formation of professional mobility future specialists services sector.

Key words: professional mobility, career development, vocational (vocational training) education, master of production training.

Мета: здійснити аналіз різних підходів до визначення сутності поняття "професійна мобільність" на прикладі ДНЗ "Хмельницький центр професійно-технічної освіти сфери послуг"; розглянути роль майстрів виробничого навчання у формуванні професійної мобільності учнів; визначити основні форми методичної роботи, спрямовані на професійний розвиток майстрів виробничого навчання.

Постановка проблеми в загальному вигляді. Основними викликами сучасного європейського суспільства в контексті освітніх модернізаційних трансформацій є професійна мобільність фахівця - вихованця будь-якої з освітніх систем, що надалі стає гарантом його кар'єрного зростання. За визначенням, поданому в Енциклопедичному словнику "Освіта дорослих", "Мобільність в освіті це можливість для будь-кого, хто навчається, побудувати свою освітню траєкторію, яка найбільш повно відповідала б його освітнім і професійним здібностям і потребам, незалежно від місцезнаходження" [1, c. 232]. Професійна мобільність є однією з форм "соціальної мобільності, що являє собою процес зміни робіт- никами місця праці" [2, с. 725]. В основу професійної мобільності "покладено закони розподілу і зміни праці, відновлення робочої сили, підвищення потреб, а також такі закономірності групової та суспільної свідомості, як норми та цінності, мотиви поведінки і потреби" [2, c. 725]. Вагомим у тлумаченні професійної мобільності бачиться те, що "чим вища спроможність робітника адаптуватися до змін, які відбуваються в економіці, техніці, технологіях тощо, то вищою $\epsilon$ його професійна мобільність" [2, с. 725].

Отже, фахівцю, орієнтованому на професійний розвиток, уже недостатньо мати знання, уміння та навички в рамках певної професії. Він повинен сформувати в процесі навчання уявлення про власну професійну каp'єру та навички активної поведінки на ринку праці, навчитися управляти своїм професійним розвитком, сприймати й акумулювати інформацію із суміжних галузей тощо. Одним із концептів, що відображає результат довгострокової активності особистості у професійній сфері, є професійна мобільність і кар'єрне зростання.

Аналіз досліджень і публікацій. У багатьох наукових дослідженнях проблема професійної мобільності в кар'єрному зростанні майбутнього фахівця є ключовою. Вона характеризується як показник якості професійної освіти (Л. Сушенцева) [3]; фактор професійної успішності (Т. Прохоренко) [4]; як складова системи професійного розвитку фахівця (H. Сургунд) [5]; як фахова якість майбутнього спеціаліста (Н. Брижак) [6].

У визначенні сутності професійної мобільності доцільно врахувати думку Н. Хакімової, котра стверджує, 
що професійна мобільність є дволикою, адже виступає як соціальний фактор, який сприяє гармонізації процесів динамічних змін суспільства; з іншого боку, має індивідуально-особистісний характер і є фактором інтраособистісної гармонізації особистості фахівця [7].

Дослідник Є. Порцевська вбачає у професійній мобільності інтегративну якість особистості, що об'єднує в собі сформовану внутрішню потребу у професійній мобільності, здібності та знання основ професійної мобільності [8, с. 64]. Водночас слушним є переконання В. Любарець, яке полягає у тому, що професійно мобільна особистість характеризується розвинутою критичністю, гнучкістю й оригінальністю мислення, незалежністю суджень, ініціативністю і наполегливістю, готовністю ризикувати, висловлювати сміливі ідеї й гіпотези, відстоювати їх 3 допомогою умінь діяти адекватно у відповідних ситуаціях, здатності оперативно адаптуватися до нових вимог, реагувати на сучасні виклики, навчатися упродовж усього життя, саморозвиватися та самоудосконалюватись [9].

Важливою для наших подальших розвідок щодо професійної мобільності та їі зв'язку з кар'єрним зростанням фахівця є думка I. Шпекторенко, стосовно того, що професійна мобільність визначається не лише здатністю особистості змінювати свою професію, місце і напрям діяльності, але й умінням приймати самостійні і нестандартні рішення, спрямовані на підвищення рівня професіоналізму, засвоювати нове освітнє, професійне, соціальне і національне середовище. На переконання науковця, переважно результатом професійної мобільності стає ефективна трудова діяльність. Виходячи з цього, I. Шпекторенко пропонує структуру професійної мобільності представити у вигляді:

1) здатності особистості досить швидко й успішно опанувати нову техніку і технологію, набувати знань та вмінь, які забезпечать ефективність нової професійної діяльності;

2) рухливості особистості, спроможності іiі до динамічного нарощування власного ресурсу, швидкого пересування, змін;

3) ознак кар'єрного просування та розвитку індивіда;

4) процесу переходу індивіда або професійної групи з однієї професійної позиції в іншу [10, с. 7$]$.
Виклад основного матеріалу дослідження. У Державному навчальному закладі "Хмельницький центр професійно-технічної освіти сфери послуг" велику увагу приділяють саме професійній мобільності майбутніх кваліфікованих робітників. Ця професійна мобільність сприймається як одна 3 умов успішного кар'єрного зростання особистості. Здатність досить швидко й успішно опанувати нову техніку і технології, набувати знань та вмінь, які забезпечують ефективність нової фахової діяльності, гарантується професійною підготовкою в Навчально-практичному центрі сучасних швейних технологій та дизайну, створеному на базі закладу в межах всеукраїнського пілотного проекту. Його головне завдання полягає у здійсненні зв'язку між закладами професійної освіти, швейними підприємствами, підприємствами-виробниками сучасних тканин, обладнання для прискорення передачі інформації з новітніх прогресивних технологій і впровадження їх у навчально-виробничий процес. Саме тут відбувається активне застосування інноваційних виробничих технологій, запровадження дуальної форми навчання у систему підготовки кваліфікованих кадрів.

Особливу роль у формуванні професійної мобільності майбутніх робітників швейної галузі відіграє співпраця з Хмельницьким національним університетом. Викладачі кафедри технології та конструювання швейних виробів проводять майстер-класи, діляться своїми творчими здобутками у напрямі створення колекцій одягу.

Особливо важливим у формуванні професійної мобільності майбутніх кваліфікованих робітників $€$ вплив їхніх наставників - майстрів виробничого навчання, котрі забезпечують високий рівень професійної підготовки майбутніх робітників. Роль майстра виробничого навчання у формуванні професійної мобільності майбутнього фахівця незаперечна. Він $є$ взірцем для учнів упродовж усього періоду здобуття професії, забезпечуючи формування у своїх вихованців фахових компетенцій, які необхідні для подальшого професійного зростання.

Тому майстер повинен приділяти увагу власному професійному розвитку, позитивними педагогічними умовами якого є система методичної роботи закладу професійної (професійно-технічної) освіти. У ДНЗ "Хмельницький центр професійнотехнічної освіти сфери послуг" уся система роботи з майстрами виробничого навчання формується в індивідуальному порядку на основі вивчення їхніх діагностичних анкет, у яких фіксуються відповідні прогалини у методичній чи професійній майстерності. Значним важелем впливу на професійний розвиток майстрів виробничого навчання є методичні комісії закладу П(ПТ)О, у яких створюються ефективні умови для удосконалення їхньої майстерності.

Оновлення структури і змісту професійної (професійно-технічної) освіти, гуманізація іiї цілей і принципів висувають підвищені вимоги до професійних та особистісних якостей сучасного педагога професійного навчання. Важливим аспектом педагогічної діяльності є поглиблене самопізнання, педагогічна рефлексія, здатність творчо змінюватися відповідно до часу та власного потенціалу, відкритість до інновацій, гнучкість, спроможність навчатися упродовж життя. Необхідність постійного опанування нових знань та навичок упродовж усього життя у наш час стає потребою кожної людини, і це насамперед, пояснюється стрімким технологічним розвитком суспільства. Тому методичну роботу в закладах П(ПТ)О розглядають як один 3 основних шляхів підвищення педагогічної майстерності і професійної компетентності педагогічних працівників. Цілеспрямовано здійснювана методична робота є обов'язковим компонентом педагогічної праці кожного викладача, майстра виробничого навчання та вихователя, а також тією рушійною силою, яка потребує постійного оновлення знань педагогів, спонукає їх до самоосвіти і самовдосконалення.

Для ефективної організації методичної роботи з педагогами необхідно враховувати рівень їхньої професійної підготовки. 3 цією мертою проводиться діагностування: експрес-опитування, анкетування на виявлення ставлення педагогів до нововведень, самоаналіз рівня фахової майстерності. Тенденції розвитку професійної (професійно-технічної) освіти в Україні зумовили необхідність упровадження інноваційних підходів в освітньому середовищі, заміну шаблонних моделей новими, нестандартними, творчими, прогресивними, дієвими та адаптованими 
до сьогодення.

Важливу роль у забезпеченні реформування П(ПТ)О відіграє модернізація методичної роботи, що полягає у стимулюванні професійного зростання педагогічних працівників, підвищенні їх професійної майстерності, пошуку нових ефективних форм і методів навчання. Успішно реалізувати завдання щодо якісної підготовки кваліфікованих робітників, котрі досконало володіють фаховими знаннями і практичними навичками, уміло застосовують сучасні виробничі технології, матеріали та інструменти, здатен педагог, який має високий рівень професійної компетентності, інтелігентності, розвинені творчі здібності, здатність до безперервної освіти.

Метою методичної роботи в закладі освіти є допомога в подоланні труднощів, відкриття шляху до пошуку, ініціативи і творчості. Тому важливо зацікавити педагогів шляхом залучення до проведення того чи іншого заходу. Не випадково у ЗП(ПТ)О практикуються, крім загальноприйнятих, й інтерактивні форми роботи, які зацікавлюють, сприяють розвитку різного роду компетентностей, індивідуального стилю, креативності, творчих здібностей. Зокрема, ідеться про творчі звіти педагогів, котрі атестуються, педагогічні посиденьки, педагогічний лекторій "Мотивація - рушійна сила в навчанні учнів", методичний міст "Сучасний урок. Який він", семінар-практикум "Упровадження інноваційних технологій і нетрадиційних методів роботи викладачів та майстрів виробничого навчання", обмін досвідом "Проведення бінарного уроку в реалістичних умовах", "У творчій майстерні педагога", презентацію досвіду роботи.

Навчання педагогів училища відбувається в інтерактивних формах спілкування. Так, маємо на увазі, круглий стіл, диспут, консультації, інтерактивні лекції, педагогічні лекторії із застосуванням мультимедійних презентацій, відеофільмів, навчальні тренінги, семінари, семінарипрактикуми, науково-практичні семінари. Надається перевага тим формам методичної роботи, які стимулюють професійну творчість педагогів, а саме: професійні конкурси, огляди-конкурси, педагогічні виставки, виставки-презентації, креативні виставки, панорами методичних заходів; проектна діяльність, презентації ідей, творчі звіти педагогів, майстеркласи; тематичні акції, випуск педагогічних порадників для педагогів, створення мультимедійних презентацій.

Чільне місце у структурі методичної роботи посідає методична рада освітнього закладу, яка покликана координувати зусилля усіх служб закладу та творчих педагогів, діяльність котрих спрямована на забезпечення науково-методичного супроводу освітнього процесу. Методична рада обговорює i обирає варіанти навчальних планів, програм, підручників, форми і методи організації освітнього процесу. У ii компетенції організація роботи з підвищення кваліфікації та майстерності педагогічних кадрів, розвитку їх творчої ініціативи, упровадження досягнень передового педагогічного досвіду. Методична рада розглядає та ухвалює методичні доробки педагогів, звіти творчих груп. Засідання методичних рад в училищі проводяться у формі проекту, консиліуму, анонсу, прогнозу, калейдоскопа, психологічної гри тощо.

Сучасна професійна освіта характеризується значними змінами в усіх сферах свого процесу. Удосконалюються освітні стандарти, оновлюються програми, змінюються технології навчання, виховання та розвитку особистості учня. Як ніколи, теза "Кадри вирішують усе" стає актуальною, адже тільки творчий педагог може розкрити творчий потенціал учня, тільки талановитий педагог може виховати талановитого учня. Тож одним 3 основних завдань методичної роботи є розвиток творчого потенціалу педагога як важливого фактора якості сучасної професійної освіти.

Основними напрямами діяльності в розвитку творчого потенціалу педагога, на які звертається особлива увага в училищі, є забезпечення сприятливих умов для розвитку інноваційного потенціалу як кожного педагога зокрема, так і педагогічного колективу загалом, розвиток системи мотивацій до інноваційної діяльності:

- створення ситуації успіху;

- підтримка ініціатив педагогів;

- свобода дій, вільний вибір форм і методів освітнього процесу;

- оптимізація процесів самоосвіти педагогів.

На допомогу в реалізації обраних педагогами індивідуальних завдань, взаємодопомогу і підтримку, обмін напрацьованим досвідом спрямована вся система методичної роботи. Запроваджені систематичне вивчення, широка пропаганда й упровадження інноваційних ідей досвідчених педагогів. Так, маємо на увазі обговорення статей, конференції, педагогічні читання, круглі столи, семінари, педагогічні лекторії, обмін думками на педагогічних і методичних радах, засіданнях методичних комісій. Змістовна методична робота дає позитивні результати: кожен педагог поповнює своє портфоліо новими знахідками, інноваційними технологіями, інтерактивними методами.

Педагогічному працівникові, котрий прагне до особистісного зростання, самовдосконалення, не обійтися без тренінгових занять, які можуть стати програмою розвитку ефективних навичок, ключових компетенцій. Згідно $з$ планом методичної роботи щорічно проводяться педагогічні тренінги з розвитку педагогічної майстерності, метою яких є підвищення фахового рівня педагогічних кадрів, формування знань та вдосконалення навичок в опануванні ключових освітніх компетенцій. Тренінгові заняття проводяться на засіданнях школи молодого педагога, семінарахпрактикумах під час проведення тижня методичної роботи.

Висновки та перспективи подальших досліджень. У сучасних умовах розвитку суспільства на заклад професійної (професійно-технічної) освіти покладено провідну місію - створення умов для формування професійно мобільного кваліфікованого робітника. Важлива роль у такому процесі відводиться майстрам виробничого навчання, професійний розвиток яких забезпечує система методичної роботи закладу професійної (професійно-технічної) освіти. Грамотно спланована і вибудувана траєкторія професійного розвитку учнів системи професійної освіти сприяє всебічному розвитку професійного та особистісного потенціалу, що в майбутньому забезпечить їм конкурентоспроможність на ринку праці.

Здійснений науковий пошук не вичерпує всіх аспектів розглянутої проблеми. Подальшого дослідження потребують удосконалення організаційних форм формування професійної мобільності майбутніх кваліфікованих робітників. 


\section{ЛІТЕРАТУРА}

1. Калачова Л. В. Мобільність // Освіта дорослих : енциклопедичний словник / за ред. В. Г. Кременя, Ю. В. Ковбасюка; [упоряд.: Н. Г. Протасова, Ю. О. Молчанова, Т. В. Куренна; ред. рада: В. Г. Кремень, Ю. В. Ковбасюк, Н. Г. Протасова та ін.] ; Нац. акад. псд. наук України, Нац. акад. держ. упр. при Президентові України та ін. Київ : Основа, 2014. 496 с.

2. Аніщенко В. М. Професійна мобільність // Енциклопедія освіти ; гол. ред. В. Г. Кремень. К. : Юрінком Інтер, 2008. $1040 \mathrm{c}$.

3. Сушенцева Л. Л. Формування професійної мобільності майбутніх кваліфікованих робітників у професійно-технічних навчальних закладах: теорія і практика: монографія / за ред. Н. Г. Ничкало. Кривий Ріг: Вид. дім, 2011.439 c.

4. Прохоренко Т. Г. Професійна мобільність як фактор професійної успішності. Вісник Національного університету "Юридична академія України імені Ярослава Мудрого". 2017. №4 (35). С. 167-172.

5. Сургунд Н. А. Професійна мобільність як складова системи професійного розвитку сучасного фахівця. Вісник Національного університету оборони України. 2014. №3 (40). C. 340-345.

6. Брижак Н. Ю. Професійна мобільність як фахова якість майбутнього вчителя. Науковий вісник ужгородського університету. Серія: "Педагогіка. Соичіальна робота". 2016. Випуск 1 (38). С. 67-70.

7. Хакимова Н. Р. Профессиональное самоопределение личности и психологические условия его реализации в ситуации смены профессиональной деятельности: дис. ...канд. психол. наук: 19.00.01. Кемерово, 2005. 179 c.

8. Порцевская Е. Д. Факторы развития профессиональной мобильности молодого специалиста Российской Федерации. Актуальные проблемы изучения профессиональной мобильности и правосознания молодых специалистов: сб. материалов Междунар. науч.-практ. конф. (Санкт-Петербург, 27-28 сент. 2013 г.). Санкт-Петербург, 2013. С. 63-69.

9. Любарець В. В. Професійна мобільність як показник якості випускника сфери туризму. URL : http:// lib.iitta.gov.ua/id/eprint/8436

10. Шпекторенко И. В. Профессиональная мобильность государственных служащих. Образование и о-во. 2007. № 6. C. 4-9.

\section{REFERENCES}

1. Kalachova L. V. Mobil'nist' // Osvita doroslih : enciklopedichnij slovnik / za red. V. G. Kremenya, YU. V. Kovbasyuka; [uporyad.: N. G. Protasova, YU. O. Molchanova, T. V. Kurenna; red. rada: V. G. Kremen', YU. V. Kovbasyuk, N. G. Protasova ta in.] ; Nac. akad. psd. nauk Ukraïni, Nac. akad. derzh. upr. pri Prezidentovi Ukraïni [ta in.]. K. : Osnova, 2014. 496 s.

2. Anishchenko V. M. Profesijna mobil'nist' // Enciklopediya osviti / Akad. ped. Nauk Ukraïni ; golovnij red.. V. G. Kremen' - K. : YUrinkom Inter, 2008. $1040 \mathrm{~s}$.

3. Sushenceva L. L. Formuvannya profesijnoï mobil'nosti majbutnih kvalifikovanih robitnikiv u profesijnotekhnichnih navchal'nih zakladah: teoriya i praktika: monografiya / za red. N. G. Nichkalo. Krivij Rig: Vid. dim, 2011. $439 \mathrm{~s}$.

4. Prohorenko T. G. Profesijna mobil'nist' yak faktor profesijnoï uspishnosti. Visnik Nacional'nogo universitetu "YUridichna akademiya Ukraïni imeni YAroslava Mudrogo". 2017. № 4 (35). S. 167-172.

5. Surgund N. A. Profesijna mobil'nist' yak skladova sistemi profesijnogo rozvitku suchasnogo fahivcya. Visnik Nacional'nogo universitetu oboroni Ukrä̈ni. 2014. № 3 (40). S. 340-345.

6. Brizhak N. YU. Profesijna mobil'nist' yak fahova yakist' majbutn'ogo vchitelya / N.YU. Brizhak // Naukovij visnik uzhgorods'kogo universitetu. 2016. Vipusk 1 (38). S. 6770.

7. Hakimova N. R. Professional'noe samoopredelenie lichnosti i psihologicheskie usloviya ego realizacii $v$ situacii smeny professional'noj deyatel'nosti: dis. ...kand. psihol. nauk: 19.00.01. Kemerovo, 2005. 179 s.

8. Porcevskaya E. D. Faktory razvitiya professional'noj mobil'nosti molodogo specialista Rossijskoj Federacii // Aktual'nye problemy izucheniya professional'noj mobil'nosti i pravosoznaniya molodyh specialistov: sb. materialov Mezhdunar. nauch.-prakt. konf. (Sankt-Peterburg, 27-28 sent. 2013 g.). Sankt-Peterburg, 2013. S. 63-69.

9. Lyubarec' V. V. Profesijna mobil'nist' yak pokaznik yakosti vipusknika sferi turizmu. URL : http:// lib.iitta.gov.ua/id/eprint/8436

10. Shpektorenko I. V. Professional'naya mobil'nost' gosudarstvennyh sluzhashchih. Obrazovanie i o-vo. 2007. № 6. S. 4-9.

Стаття надійшла 27.05.2019 p. 